\title{
Optically Active Cyclohexene Derivative as a New Antisepsis Agent: An Efficient Synthesis of Ethyl (6R)-6-[ $N$-(2-Chloro-4-fluorophenyl)- sulfamoyl]cyclohex-1-ene-1-carboxylate (TAK-242)
}

\author{
Masami Yamada,* Takashi Ichikana, Toru Yamano, Fumio Kikumoto, Yuji Nishikimi, \\ Norikazu TAMURA, and Tomoyuki KitAZAKI \\ Pharmaceutical Research Division, Takeda Pharmaceutical Company Limited; 2-17-85 Jusohonmachi, Yodogawa-ku, \\ Osaka 532-8686, Japan. Received July 13, 2005; accepted October 20, 2005
}

Two new synthetic methods were established for the efficient synthesis of optically active cyclohexene antisepsis agent, ethyl (6R)-6-[N-(2-chloro-4-fluorophenyl)sulfamoyl]cyclohex-1-ene-1-carboxylate [(R)-1: TAK-242)]. The first method involved recrystallization from methanol of the diastereomeric mixture $\left(6 R S, 1^{\prime} R\right)-7$, obtained by esterification of carboxylic acid 3 with $(S)$-1-(4-nitrophenyl)ethanol $[(S)-5)]$ to give the desired isomer $\left(6 R, 1^{\prime} R\right)$ 7 with $\mathbf{9 9 \%}$ de in $32 \%$ yield. Subsequent catalytic hydrogenolysis and esterification gave $(R)-1$ with $>99 \%$ ee. The second method employed enantioselective hydrolysis of acetoxymethyl ester 9a (prepared by alkylation of 3 with bromomethyl acetate) with Lipase PS-D to give the eutomeric enantiomer $(R)-9$ a with excellent enantioselectivity $(>99 \%$ ee) and high yield $(48 \%)$. The desired $(R)-1$ was then obtained by transesterification with ethanol in the presence of concentrated sulfuric acid without loss of ee. Of these, the procedure employing enzymatic kinetic resolution using Lipase PS-D is the more efficient and practical preparation of $(R)-1$.

Key words TAK-242; optical resolution; lipase; cyclohexene; chiral synthesis

Sepsis and septic shock remain the chief causes of death in intensive care units, with mortality rates between 30 and $70 \%{ }^{1-3)}$ Although several drug candidates have entered clinical trials over the last 20 years, most have not demonstrated significant benefit for patients with sepsis and septic shock, and difficulties of the development of an antisepsis agent has been proven. In 2001, Drotrecogin- $\alpha$ (Xigris $\left.{ }^{\mathrm{TM}}\right),{ }^{4)}$ a recombinant human activated protein $\mathrm{C}$, was launched onto the market as the first antisepsis agent, but the usefulness of this drug is limited due to its efficacy and safety.

Recently, we reported that ethyl (6R)-6-[N-(2-chloro-4-fluorophenyl)sulfamoyl]cyclohex-1-ene-1-carboxylate [TAK-242: $(R)-1]$ was selected as a new class of clinical candidate for sepsis. ${ }^{5)}$ TAK-242 exhibited potent inhibitory activity for the production of not only nitric oxide (NO) but also various cytokines such as tumor necrosis factor-alfa (TNF- $\alpha$ ), interleukin-1-beta (IL-1 $\beta$ ) and IL-6 in vitro, as well as potent protective effects in the mouse endotoxin shock model. $(R)-\mathbf{1}$ is currently undergoing clinical trails and is expected to be a promising antisepsis drug.

As shown in Chart 1, $(R)$-1 was obtained in high enantiomeric purity by the optical resolution of $\mathrm{rac}-\mathbf{1}$, prepared from commercially available ethyl 2-oxocyclohexane-1-carboxylate (2) in three steps, by means of preparative high performance liquid chromatography (HPLC) using a chiral stationary phase. ${ }^{5}$ Although separation using preparative HPLC is a straightforward method for the preparation of small quantities of optically active compounds, applications to large scale production are sometimes troublesome. Thus, an efficient and practical process for the preparation of optically active $(R)-\mathbf{1}$ was required in order to supply sufficient quanti- ties for further evaluation of this compound. In this paper, we describe the development of two new synthetic methods of (R)-1 utilizing $r a c-1$ as the synthetic precursor.

In order to find an alternative synthesis of optically active (R)-1 from the $r a c-1$, the following two routes were proposed (Chart 2): the formation and separation of diastereomeric ester derivatives I followed by the conversion to ethyl ester (Route A), and enzymatic hydrolysis of the ester derivative (if necessary, followed by ethyl esterification, Route B).

The synthetic method via the preparation of diastereomeric phenethyl ester derivatives was initially investigated as shown in Chart 3. First, the synthesis of key intermediate carboxylic acid 3 by hydrolysis of rac-1 was examined using standard hydrolytic conditions employing bases such as sodium hydroxide $(\mathrm{NaOH})$, lithium hydroxide, potassium carbonate $\left(\mathrm{K}_{2} \mathrm{CO}_{3}\right)$ and cesium carbonate $\left(\mathrm{Cs}_{2} \mathrm{CO}_{3}\right)$ or Lewis acids and Brønsted acids. However, in all cases hydrolysis was accompanied by significant decomposition resulting in low yields of 3. In further studies, the use of barium dihydroxide $\left[\mathrm{Ba}(\mathrm{OH})_{2}\right]$ was found to give $\mathbf{3}$ in good yield. Thus, the treatment of rac-1 with aqueous $\mathrm{Ba}(\mathrm{OH})_{2}$ solution at $60^{\circ} \mathrm{C}$ in acetonitrile (MeCN) gave carboxylic acid 3 in $74 \%$ isolated yield.

Next, esterification of $\mathbf{3}$ was examined using a number of chiral alcohols including $(R)$ - and $(S)$-1-phenylethanol (4), ${ }^{6}$ $(R)$ - and $(S)$-1-(4-nitrophenyl)ethanol (5), ${ }^{6}(R)$ - and $(S)$-1-(2naphtyl)ethanol $\left.{ }^{6}\right)$ and $d$ - and $l$-menthol. Ease in separation of diastereomers and appreciable yields made $(R)-\mathbf{4}$ and $(S)-5$ the alcohols of choice. Carboxylic acid $\mathbf{3}$ was allowed to react with $(R)-\mathbf{4}$ and $(S)-5$ under usual Mitsunobu reaction conditions in tetrahydrofuran (THF) to give the correspond-

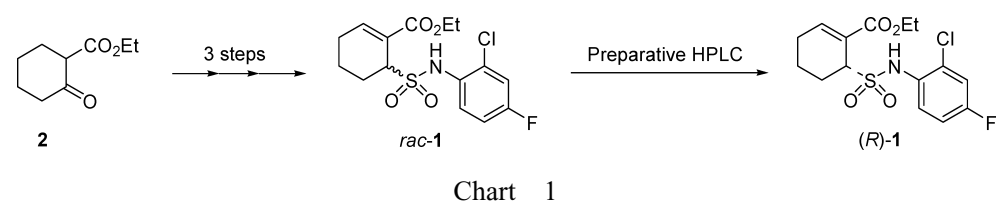



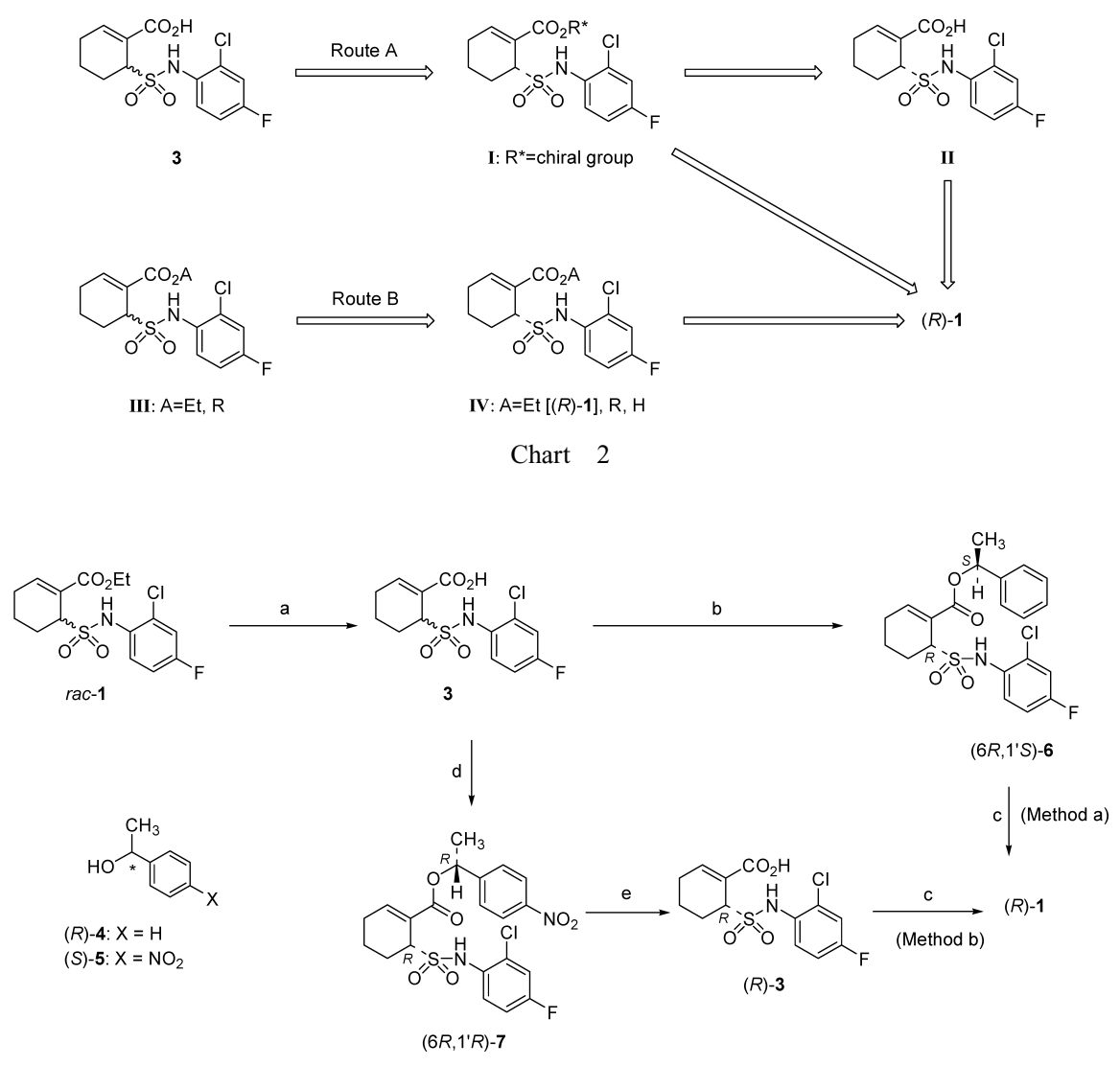

Reagents: (a) $\mathrm{Ba}(\mathrm{OH})_{2}, \mathrm{MeCN}, 60^{\circ} \mathrm{C}(74 \%)$; (b) $(R)$-4, $\mathrm{PPh}_{3}$, DEAD, THF (32\% yield, $59 \%$ de); (c) EtOH, conc. $\mathrm{H}_{2} \mathrm{SO}_{4}$ (Method a: $37 \%$; Method b: $72 \%)$; (d) $(S)-5, \mathrm{PPh}_{3}$, DEAD, THF ( $32 \%$ yield, $99 \%$ de); (e) $\mathrm{H}_{2}, 10 \%$ Pd-C $(84 \%)$.

Chart 3

ing diastereomeric esters $\left(6 R S, 1^{\prime} S\right)-6$ and $\left(6 R S, 1^{\prime} R\right)-7$, respectively. Diastereomeric mixture $\left(6 R S, 1^{\prime} S\right)$-6 was separated by silica gel column chromatography to preferentially give the desired isomer $\left(6 R, 1^{\prime} S\right)-6^{7)}$ with $59 \%$ diastereomeric excess $(\mathrm{de})^{8)}$ in $32 \%$ yield. The use of a similar procedure afforded $\left(6 R, 1^{\prime} R\right)-7^{9)}$ in $32 \%$ yield with excellent diastereomeric purity $\left(99 \%\right.$ de) ${ }^{10)}$ Replacement of the 1-phenethyl group of $\left(6 R, 1^{\prime} S\right)-6(59 \%$ de) with an ethyl group was subsequently carried out by transesterification, followed by crystallization from ethanol $(\mathrm{EtOH})$ to give $(R)-\mathbf{1}$ with $>99 \%$ enantiomeric excess (ee). ${ }^{11)}$ However, the yield of $(R)-\mathbf{1}$ was low $(37 \%)$ due to the low diastereomeric purity of $\left(6 R, 1^{\prime} S\right)-6$ used. In contrast, $\left(6 R, 1^{\prime} R\right)-7$ with $99 \%$ de was hydrolyzed to carboxylic acid $(R)-3$ in $84 \%$ yield by catalytic hydrogenolysis over palladium on carbon $(\mathrm{Pd}-\mathrm{C})$ in acetic acid $(\mathrm{AcOH})$, and subsequent esterification with $\mathrm{EtOH}$ in the presence of concentrated sulfuric acid (conc. $\mathrm{H}_{2} \mathrm{SO}_{4}$ ) gave $(R)-1$ in $72 \%$ isolated yield with $>99 \%$ ee $^{12)}$ Both products $(R)-1$ obtained via the diastereomeric esters, $\left(6 R, 1^{\prime} S\right)-6$ and $\left(6 R, 1^{\prime} R\right)-7$, were identical to an authentic sample prepared by HPLC separation. $^{5)}$

As described above, a high yielding synthetic route for $(R)-1$ in high enantiomeric purity was established via the separation of diastereomeric ester $\left(6 R S, 1^{\prime} R\right)-7$. This procedure, however, have remained unattractive due to annoying column chromatography and availability of the optically active alcohol $(S)-5$.

Our next approach to obtain optically active $(R)-\mathbf{1}$ was to examine the use of enzymatic reaction. Kinetic optical reso-

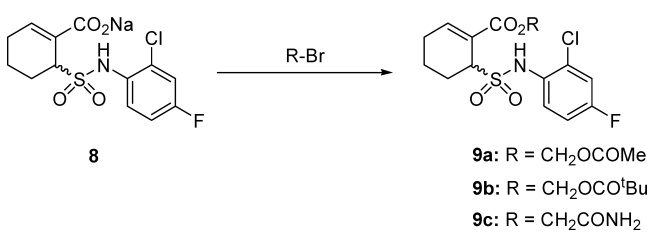

Chart 4

lution with enzymes has received considerable attention because of the high enantioselectivities than can be obtained. ${ }^{13-21)}$ Thus, a selection of enzymes was screened in order to identify those which were capable of catalyzing the enantioselective hydrolysis of $r a c-\mathbf{1}$, however in all cases no hydrolysis was observed. It is known that enzymatic hydrolysis of sterically hindered esters can be problematic, ${ }^{22,23)}$ and this suggested that the $\mathrm{A}^{1,2}$-strain between the ethoxycarbonyl group and sulfamoyl group of rac-1 was preventing hydrolysis. Achiwa and co-workers introduced acyloxymethyl or carbamoylmethyl groups into the sterically hindered carboxylic acid, and successfully achieved enantioselective enzymatic hydrolysis. ${ }^{22,23)}$ Accordingly, it was thought that exchange of the ethyl group of $\mathrm{rac}-1$ to acyloxymethyl and carbamoylmethyl group may generate a suitable ester substrate for enantioselective enzymatic hydrolysis. Esters $9 \mathbf{a}-\mathbf{c}$ were synthesized by alkylation of $\mathbf{8}^{5)}$ as shown in Chart 4, and were screened for hydrolysis using various lipases. It was found that several lipases catalyzed the enantioselective hydrolysis of acetoxymethyl ester 9a to opti- 


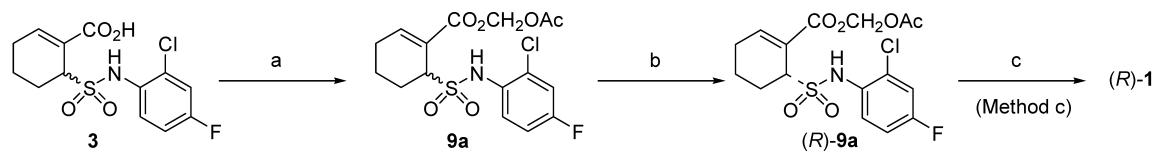

Reagents: (a) $\mathrm{BrCH}_{2} \mathrm{OAc}, \mathrm{Cs}_{2} \mathrm{CO}_{3}$, TBAI, MeCN, $50^{\circ} \mathrm{C}$ (72\%); (b) Lipase PS-D, acetone (48\% yield, $>99 \%$ ee); (c) EtOH, conc. $\mathrm{H}_{2} \mathrm{SO}_{4}$ ( $65 \%$ yield, $>99 \%$ ee).

Chart 5

Table 1. Enantioselective Hydrolysis of Acetoxymethyl Ester 9a with Various Lipases $^{a}$ )

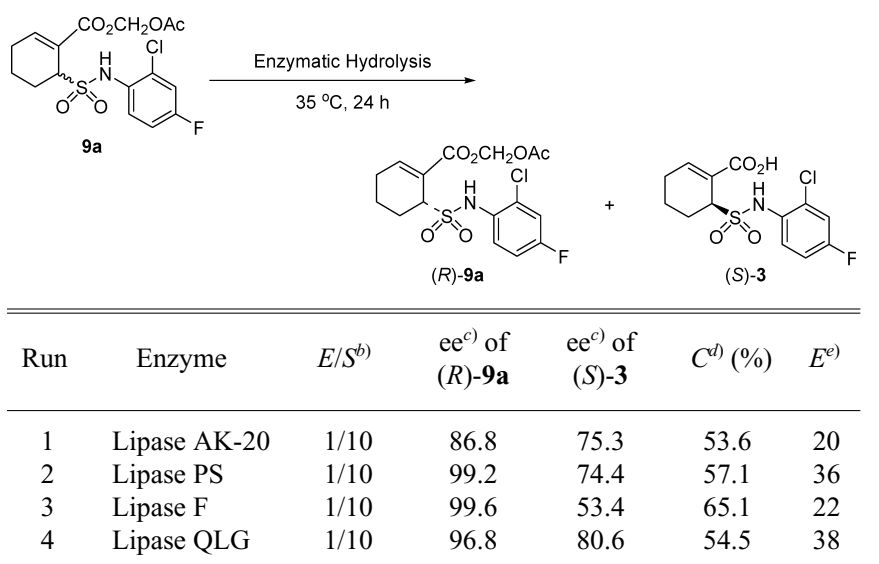

a) The reaction was carried out for $24 \mathrm{~h}$ at $35^{\circ} \mathrm{C}$ in tert-BME containing ca. $5 \%$ water. Concentration of substrate 9a to solvent was $1 \mathrm{mg} / \mathrm{ml}$. b) $E / S$, enzyme to substrate ratio (w/w). c) Determined by HPLC analysis. d) $C$, conversion as determined by HPLC analysis. e) Calculated according to Chen et $\mathrm{al}^{27)}$

cally active $(R)-9 \mathbf{a}^{24)}$ and thus $9 \mathbf{a}$ was selected for use as the enzymatic hydrolysis substrate.

More practical synthesis of key intermediate 9a was carried out by esterification of carboxylic acid $\mathbf{3}$, and optimization of the base, solvent and additive, ${ }^{25}$ indicated that reaction of 3 with bromomethyl acetate in the presence of $\mathrm{Cs}_{2} \mathrm{CO}_{3}$ and tetrabutylammonium iodide (TBAI) at $50^{\circ} \mathrm{C}$ in $\mathrm{MeCN}$ gave 9a in $72 \%$ isolated yield (Chart 5).

Next, the hydrolysis of 9a was examined by using fifty lipases including Lipase AK-20, PS, F and QLG. ${ }^{26)}$ The typical reaction was carried out as follows: a mixture of $9 \mathbf{a}$ and lipase in tert-butylmethyl ether (tert-BME) containing ca. $5 \%$ water was stirred for $24 \mathrm{~h}$ at $35^{\circ} \mathrm{C}$. As shown in Table 1, the four lipases gave $(R)-9$ a with high enantiomeric purity $(>86 \%$ ee), although Lipase PS and Lipase F showed the highest enantioselectivity. In addition, the $E$-value ${ }^{27,28)}$ using Lipase PS was considerably superior to that using Lipase F and thus Lipase PS was selected as the enzyme catalyst for this hydrolysis.

Taking into account an application to large scale preparation, it appeared that it would be more appropriate to use $\mathrm{Li}$ pase PS immobilized on diatomaceous earth (Lipase PS-D) ${ }^{29)}$ to address issues of ease of operation, stability and cost. Therefore, further optimization of the reaction conditions was carried out using Lipase PS-D.

As shown in Table 2, when 9a was treated with Lipase PSD under the same conditions as used with Lipase PS, a decrease in $E$-value was observed (runs $1 v s$. 2). This $E$-value was significantly improved by increasing the proportion of both water to solvent and enzyme to substrate (run 3). Unfortunately, the poor solubility of substrate 9a in tert-BME ( $c$ a. $1 \mathrm{mg} / \mathrm{ml}$ ) would require the use of a large quantity of this sol- vent. Though lipases are more stable in more hydrophobic solvents, ${ }^{30)}$ polar or hydrophilic solvents were investigated to identify a more suitable solvent with improved solubility for 9a. The examination of $\mathrm{MeCN}$ and acetone were carried out under the conditions in Table 2 (runs 4 and 5). Surprisingly, the reaction rate and $E$-value using acetone were nearly equal to those using tert-BME (runs 3 and 5), and thus subsequent optimization of the reaction conditions was carried out in acetone.

It was found that the best result was obtained when the concentration of 9 a was $50 \mathrm{mg} / \mathrm{ml}$ and the ratio of Lipase PS$\mathrm{D}$ to $9 \mathrm{a}$ was 3 to 5. Thus, a mixture of 9a and Lipase PS-D in acetone containing $c a$. $10 \%$ water was stirred for $20 \mathrm{~h}$ at $28^{\circ} \mathrm{C}$ to afford $(R)-9 \mathrm{a}$ with excellent enantiomeric purity ( $>99 \%$ ee) and $E$-value (137) (run 6). To investigate the practicality of this enzymatic procedure, the synthesis of $(R)$ 1 was carried out starting from $10 \mathrm{~g}$ of $9 \mathbf{a}$. Firstly 9a was hydrolyzed under the conditions of run 6 to give $(R)-9 \mathbf{a}$ in $48 \%$ isolated yield with $>99 \%$ ee, without column purification. The isolation procedure for this synthesis was highly convenient requiring only removal of the enzyme by filtration and standard work-up (washing with alkaline water). Avoidance of laborious column chromatography rendered this procedure quite practical. Transesterification of the resulting $(R)-9 \mathbf{a}$ was then carried out with EtOH in the presence of conc. $\mathrm{H}_{2} \mathrm{SO}_{4}$ to give $(R)-1$ in $65 \%$ isolated yield with $>99 \%$ ee (Chart 5).

In conclusion, we have established two new methods for the efficient synthesis of $(R)-1$ that avoid the use of optical resolution by HPLC. Of these, the procedure employing enzymatic kinetic resolution using Lipase PS-D is the more efficient and practical preparation of $(R)-\mathbf{1}$ (TAK-242).

\section{Experimental}

Melting points were determined using a Yanagimoto melting point apparatus and are uncorrected. IR spectra were obtained on Shimadzu FTIR$8200 \mathrm{PC}$ spectrometer. ${ }^{1} \mathrm{H}-\mathrm{NMR}$ spectra were recorded on Varian Gemini $200(200 \mathrm{MHz})$ spectrometer or Varian Mercury 300 (300 MHz) spectrometer with tetramethylsilane as an internal standard. The following abbreviations are used: $\mathrm{s}=$ singlet, $\mathrm{d}=$ doublet, $\mathrm{t}=$ triplet, $\mathrm{q}=$ quartet, $\mathrm{m}=$ multiplet and $\mathrm{br}=$ broad. The optical rotations were recorded with a Jasco DIP-181 or DIP-370 digital polarimeter. FAB mass spectra were recorded on a JEOL JMS-HX110. Elemental analyses were carried out by Takeda Analytical Laboratories Ltd. and were within $\pm 0.4 \%$ of the theoretical values for the elements indicated unless otherwise noted.

Reactions were carried out at room temperature unless otherwise noted and followed by TLC on silica gel $60 \mathrm{~F}_{254}$ precoated TLC plates (E. Merck) or by HPLC using an octadecyl silica (ODS) column (YMC-Pack A-303, $4.6 \mathrm{~mm}$ i.d. $\times 250 \mathrm{~mm}$, YMC Co., Ltd.). Standard work-up procedures were as follows. The reaction mixture was partitioned between the indicated solvent and water. Organic extracts were combined and washed in the indicated order using the following aqueous solutions: water, $5 \%$ aqueous sodium carbonate solution (aqueous $\mathrm{NaHCO}_{3}$ ), saturated sodium chloride $(\mathrm{NaCl})$ solution (brine), $1 \mathrm{~N}$ aqueous sodium hydroxide solution $(1 \mathrm{~N} \mathrm{NaOH})$ and $1 \mathrm{~N}$ hydrochloric acid $(1 \mathrm{~N} \mathrm{HCl})$. Extracts were dried over anhydrous magnesium sulfate $\left(\mathrm{MgSO}_{4}\right)$, filtered and evaporated in vacuo. Chromatographic separations were carried out on Silica gel $60(0.063-0.200 \mathrm{~mm}$, E. Merck) using the indicated eluents. 
Table 2. Lipase PS-D Catalyzed Enantioselective Hydrolysis of 9a ${ }^{a)}$

\begin{tabular}{|c|c|c|c|c|c|c|c|c|}
\hline Run & Solv. $(\text { Conc., } \mathrm{mg} / \mathrm{ml})^{b)}$ & W/Solv. ${ }^{c}$ & $E / S^{(d)}$ & Time (h) & $\mathrm{ee}^{e)}$ of $(R)-9 \mathbf{a}$ & $\mathrm{ee}^{e)}$ of $(S)-\mathbf{3}$ & $C^{f)}(\%)$ & $E^{g)}$ \\
\hline $1^{h)}$ & tert-BME (1) & $1 / 20$ & $1 / 7.4$ & 24 & $>99$ & 69.5 & 59.0 & 48 \\
\hline 2 & tert-BME (1) & $1 / 20$ & $1 / 7.4$ & 30 & 97.9 & 78.6 & 55.3 & 34 \\
\hline 3 & tert-BME (1) & $1 / 10$ & $1 / 5$ & 18 & $>99$ & 74.5 & 57.3 & 93 \\
\hline 4 & $\operatorname{MeCN}(20)$ & $1 / 10$ & $2 / 5$ & 74 & 89.6 & 91.4 & 49.5 & 68 \\
\hline 5 & Acetone (20) & $1 / 10$ & $2 / 5$ & 20 & 81.7 & 94.5 & 46.4 & 91 \\
\hline 6 & Acetone (50) & $1 / 10$ & $3 / 5$ & 20 & $>99$ & 84.9 & 54.1 & 137 \\
\hline
\end{tabular}

a) The reaction was carried out at $28^{\circ} \mathrm{C}$. b) Conc., concentration of substrate. c) W/Solv., water to solvent ratio (v/v). d) $E / S$, enzyme to substrate ratio (w/w). e) Determined by HPLC analysis. f) $C$, conversion as determined by HPLC analysis. $g$ ) Calculated according to Chen $e t$ al. ${ }^{27)} h$ ) Using Lipase PS.

The de's of the compounds prepared were determined by HPLC using an ODS column (YMC-Pack A-303) or silica gel column (YMC-Pack SIL) under the indicated conditions [column; mobile phase; flow rate; detection].

The ee's of the compounds prepared were determined by HPLC using a chiral stationary phase column (CHIRALCEL OC and CHIRALPAK AD, $4.6 \mathrm{~mm}$ i.d. $\times 250 \mathrm{~mm}$, Daicel Chemical Industries, Ltd.) under the indicated conditions [column; mobile phase; flow rate; detection].

The following lipases were obtained from the Amano Enzyme Inc.: Lipase AK-20, Lipase PS and Lipase PS-D. Lipase F was produced by Biocatalysts Ltd. Lipase QLG was a product of Meito Sangyo Co., Ltd.

(6RS)-6-[ $N$-(2-Chloro-4-fluorophenyl)sulfamoyl]cyclohex-1-ene-1-carboxylic Acid (3) A hot aqueous $\mathrm{Ba}(\mathrm{OH})_{2} \cdot 8 \mathrm{H}_{2} \mathrm{O}(26.0 \mathrm{~g})$ solution $(110 \mathrm{ml})$ heated at $70^{\circ} \mathrm{C}$ was added to a solution of $1^{5)}(10.0 \mathrm{~g})$ in $\mathrm{MeCN}(150 \mathrm{ml})$. The mixture was stirred for $1 \mathrm{~h}$ at $60^{\circ} \mathrm{C}$ and cooled, then poured into $1 \mathrm{~N}$ $\mathrm{HCl}(300 \mathrm{ml})$. The whole was extracted with ethyl acetate (EtOAc, $150 \mathrm{ml}$ ) and the organic layer was extracted with $1 \mathrm{~N} \mathrm{NaOH}(300 \mathrm{ml})$. The alkaline aqueous extract was washed with EtOAc $(150 \mathrm{ml})$ and acidified with $10 \%$ citric acid $(500 \mathrm{ml})$. The whole was worked up (EtOAc; brine). The residue was crystallized from EtOAc-hexane to give $3(6.82 \mathrm{~g}, 74 \%)$ as white powdery crystals, mp $187-189^{\circ} \mathrm{C} .{ }^{1} \mathrm{H}-\mathrm{NMR}$ (DMSO- $\left.d_{6}\right) \delta: 1.55-1.80(2 \mathrm{H}$, m), $1.99-2.46(4 \mathrm{H}, \mathrm{m}), 4.33(1 \mathrm{H}, \mathrm{d}, J=4.8 \mathrm{~Hz}), 7.08(1 \mathrm{H}, \mathrm{br} \mathrm{s}), 7.22(1 \mathrm{H}$, $\mathrm{dt}, J=8.6,3.0 \mathrm{~Hz}), 7.48-7.59(2 \mathrm{H}, \mathrm{m}), 9.64(1 \mathrm{H}, \mathrm{br} \mathrm{s}), 12.35(1 \mathrm{H}, \mathrm{br} \mathrm{s})$. Anal. Calcd for $\mathrm{C}_{13} \mathrm{H}_{13} \mathrm{ClFNO}_{4} \mathrm{~S}$ : C, 46.78; H, 3.93; N, 4.20. Found: $\mathrm{C}$, $46.82 ; \mathrm{H}, 4.22 ; \mathrm{N}, 4.03$.

(1'S)-1'-Phenylethyl (6R)-6-[ $N$-(2-Chloro-4-fluorophenyl)sulfamoyl]cyclohex-1-ene-1-carboxylate $\left[\left(6 R, 1^{\prime} S\right)-6\right]$ A solution of diethyl azodicarboxylate (DEAD, $40 \%$ in toluene, $5.22 \mathrm{~g}$ ) in THF $(60 \mathrm{ml})$ was added dropwise to an ice-cooled solution of $(R)-4(7.32 \mathrm{~g})$, triphenylphosphine $\left(\mathrm{PPh}_{3}\right.$, $15.7 \mathrm{~g})$ and $3(20.0 \mathrm{~g})$ in THF $(200 \mathrm{ml})$ over a period of $30 \mathrm{~min}$. The mixture was stirred for $6 \mathrm{~h}$ under a nitrogen atmosphere and worked up (EtOAc; $0.1 \mathrm{~N}$ $\mathrm{NaOH}$, water, brine). A mixture of EtOAc-hexane $(1: 2, \mathrm{v} / \mathrm{v}, 200 \mathrm{ml})$ was added to the residue. The resulting insoluble substances were filtered off, and the filtrate was concentrated under reduced pressure. The residue was purified by silica gel column chromatography (EtOAc-hexane, $1: 9 \rightarrow 1: 6$, $\mathrm{v} / \mathrm{v})$ to give $\left(6 R, 1^{\prime} S\right)-6(10.5 \mathrm{~g}, 32 \%)$ as white crystals with $59 \%$ de [column, YMC-pack ODS A-303; mobile phase, methanol $(\mathrm{MeOH})-\mathrm{H}_{2} \mathrm{O}-\mathrm{AcOH}$, 7:3:0.02; flow rate, $0.8 \mathrm{ml} / \mathrm{min}$; detection, $\mathrm{UV}$ at $254 \mathrm{~nm}$; retention time, $\left.\left(6 R, 1^{\prime} S\right)-6: 35 \mathrm{~min},\left(6 S, 1^{\prime} S\right)-6: 32 \mathrm{~min}\right]$, which was used for the next step without purification.

The purification of $\left(6 R, 1^{\prime} S\right)-6$ was independently carried out and $\left(6 R, 1^{\prime} S\right)-6$ with $97 \%$ de was isolated, whose analytical data was shown below: ${ }^{1} \mathrm{H}-\mathrm{NMR}$ (DMSO- $\left.d_{6}\right) \delta: 1.42(3 \mathrm{H}, \mathrm{d}, J=6.6 \mathrm{~Hz}), 1.50-1.85(2 \mathrm{H}$, m), $2.00-2.49(4 \mathrm{H}, \mathrm{m}), 4.32(1 \mathrm{H}, \mathrm{d}, J=4.8 \mathrm{~Hz}), 5.76(1 \mathrm{H}, \mathrm{q}, J=6.6 \mathrm{~Hz})$, $7.14-7.31(7 \mathrm{H}, \mathrm{m}), 7.48-7.55(2 \mathrm{H}, \mathrm{m}), 9.72(1 \mathrm{H}, \mathrm{brs})$. Anal. Calcd for $\mathrm{C}_{21} \mathrm{H}_{21} \mathrm{ClFNO}_{4} \mathrm{~S}$ : C, 57.60; H, 4.83; N, 3.20. Found: C, 57.64; H, 4.91; N, 3.24 .

$\left(1^{\prime} R\right)-1^{\prime}$-(4-Nitrophenyl)ethyl (6R)-6-[ $N$-(2-Chloro-4-fluorophenyl)sulfamoyl]cyclohex-1-ene-1-carboxylate $\left[\left(6 R, 1^{\prime} R\right)-7\right]$ A solution of DEAD $(40 \%$ in toluene, $22.8 \mathrm{ml})$ in THF $(270 \mathrm{ml})$ was added dropwise to an icecooled solution of $(S)-5(6.7 \mathrm{~g}), \mathrm{PPh}_{3}(13.2 \mathrm{~g})$ and $\mathbf{3}(16.8 \mathrm{~g})$ in THF $(270 \mathrm{ml})$ over a period of $1 \mathrm{~h}$. After having been stirred for $7 \mathrm{~h}$ under a nitrogen atmosphere, the reaction mixture was concentrated under reduced pressure and toluene $(50 \mathrm{ml})$ was added. The resulting insoluble substances were removed by filtration, and the filtrate was concentrated under reduced pressure. The residue was subjected to silica gel chromatography (EtOAchexane, $1: 5, \mathrm{v} / \mathrm{v})$ to afford $\left(6 R S, 1^{\prime} R\right)-7(20.5 \mathrm{~g})$, which was dissolved in cooled $\mathrm{MeOH}(15 \mathrm{ml})$ and the solution was stirred for $30 \mathrm{~min}$ at $0{ }^{\circ} \mathrm{C}$. The crystalline precipitates were collected by filtration and recrystallized from cooled $\mathrm{MeOH}$ to give $\left(6 R, 1^{\prime} R\right)-7(6.24 \mathrm{~g}, 32 \%)$ as white crystals. The de of $\left(6 R, 1^{\prime} R\right)-7$ obtained was determined to be $99.5 \%$ [column, YMC-pack SIL; mobile phase, EtOAc-hexane, 1:5; flow rate, $0.8 \mathrm{ml} / \mathrm{min}$; detection, UV at $220 \mathrm{~nm}$; retention time, $\left(6 R, 1^{\prime} R\right)-7$ : $\left.13.2 \mathrm{~min},\left(6 S, 1^{\prime} R\right)-7: 11.2 \mathrm{~min}\right] . \mathrm{mp}$ $103-104{ }^{\circ} \mathrm{C} .{ }^{1} \mathrm{H}-\mathrm{NMR}$ (DMSO- $\left.d_{6}\right) \delta: 1.31(3 \mathrm{H}, \mathrm{d}, J=6.6 \mathrm{~Hz}), 1.66-2.55$ $(6 \mathrm{H}, \mathrm{m}), 4.34(1 \mathrm{H}, \mathrm{d}, J=5.2 \mathrm{~Hz}), 5.87(1 \mathrm{H}, \mathrm{q}, J=6.6 \mathrm{~Hz}), 7.14-7.24(2 \mathrm{H}$, m), 7.48-7.57 (2H, m), $7.50(2 \mathrm{H}, \mathrm{d}, J=8.8 \mathrm{~Hz}), 8.17(2 \mathrm{H}, \mathrm{d}, J=8.8 \mathrm{~Hz})$, $9.82(1 \mathrm{H}, \mathrm{s})$. IR $(\mathrm{KBr}) \mathrm{cm}^{-1}: 3218,1713,1520,1495,1348,1329,1254$, 1148, 1067. $[\alpha]_{\mathrm{D}}^{20}+112.2^{\circ}(c=1.0, \mathrm{MeOH})$. Anal. Calcd for $\mathrm{C}_{21} \mathrm{H}_{20}$ $\mathrm{ClFN}_{2} \mathrm{O}_{6} \mathrm{~S}: \mathrm{C}, 52.23 ; \mathrm{H}, 4.17 ; \mathrm{N}, 5.80$. Found: C, 52.07; H, 4.12; N, 5.92.

(6R)-6-[ $\mathrm{N}$-(2-Chloro-4-fluorophenyl)sulfamoyl]cyclohex-1-ene-1-carboxylic Acid [(R)-3] A solution of $\left(6 R, 1^{\prime} R\right)-7(5.0 \mathrm{~g}, 99.5 \% \mathrm{de})$ in $\mathrm{AcOH}$ $(300 \mathrm{ml})$ was hydrogenated over $10 \% \mathrm{Pd}-\mathrm{C}(50 \%$ wet, $5.0 \mathrm{~g})$ for $2 \mathrm{~h}$ under an atmospheric pressure. The catalyst was removed by filtration, and the filtrate was concentrated under reduced pressure. The residue was dissolved in EtOAc $(200 \mathrm{ml})$ and the whole was extracted with $1 \mathrm{~N} \mathrm{NaOH}(200 \mathrm{ml} \times 2)$. The aqueous extracts were combined and neutralized with $1 \mathrm{~N} \mathrm{HCl}(500 \mathrm{ml})$, then the whole was worked up (EtOAc; brine). The residue was crystallized from EtOAc-hexane to give $(R)-3(2.92 \mathrm{~g}, 84 \%)$ as white powdery crystals with $>99 \%$ ee [column, CHIRALCEL OC; mobile phase, hexane-EtOHtrifluoroacetic acid (TFA), $8: 2: 0.01$; flow rate, $0.8 \mathrm{ml} / \mathrm{min}$; detection, $\mathrm{UV}$ at $225 \mathrm{~nm}$; retention time, $(R)-3: 10.5 \mathrm{~min},(S)-3: 14.4 \mathrm{~min}] . \mathrm{mp} 157.5-158.0^{\circ} \mathrm{C}$. ${ }^{1} \mathrm{H}-\mathrm{NMR}$ (DMSO- $\left.d_{6}\right) \delta: 1.50-2.52(6 \mathrm{H}, \mathrm{m}), 4.32(1 \mathrm{H}, \mathrm{d}, J=4.4 \mathrm{~Hz}), 7.08$ $(1 \mathrm{H}, \mathrm{t}, J=2.8 \mathrm{~Hz}), 7.17-7.27(1 \mathrm{H}, \mathrm{m}), 7.47-7.60(2 \mathrm{H}, \mathrm{m}), 9.60(1 \mathrm{H}, \mathrm{br} \mathrm{s})$, 12.35 (1H, br s). IR (KBr) cm ${ }^{-1}: 3216,1709,1495,1327,1223,1144,1134$. $[\alpha]_{\mathrm{D}}^{20}+109.7^{\circ}(c=0.994, \mathrm{MeOH})$. Anal. Calcd for $\mathrm{C}_{13} \mathrm{H}_{13} \mathrm{ClFNO}_{4} \mathrm{~S}: \mathrm{C}$, 46.78; H, 3.93; N, 4.20. Found: C, 46.89; H, 4.11; N, 4.27.

Acetoxymethyl (6RS)-6-[N-(2-Chloro-4-fluorophenyl)sulfamoyl]cyclohex-1-ene-1-carboxylate (9a) A mixture of $3(10.0 \mathrm{~g})$, bromomethyl acetate $(6.41 \mathrm{~g}), \mathrm{Cs}_{2} \mathrm{CO}_{3}(5.86 \mathrm{~g})$, TBAI $(5.54 \mathrm{~g})$ and $\mathrm{MeCN}(200 \mathrm{ml})$ was stirred for $2.5 \mathrm{~h}$ at $52-55^{\circ} \mathrm{C}$ under a nitrogen atmosphere. The mixture was cooled and worked up (EtOAc; $0.5 \mathrm{~N} \mathrm{HCl}$, brine). The residue was crystallized from diisopropyl ether (iso- $\left.\mathrm{Pr}_{2} \mathrm{O}\right)$ to give $9 \mathrm{9a}(8.75 \mathrm{~g}, 72 \%)$ as white powdery crystals, mp $129-130{ }^{\circ} \mathrm{C} .{ }^{1} \mathrm{H}-\mathrm{NMR}$ (DMSO- $d_{6}$ ) $\delta: 1.60-1.80$ $(2 \mathrm{H}, \mathrm{m}), 2.02(3 \mathrm{H}, \mathrm{s}), 2.02-2.46(4 \mathrm{H}, \mathrm{m}), 4.29(1 \mathrm{H}, \mathrm{d}, J=5.2 \mathrm{~Hz}), 5.64$ $(2 \mathrm{H}, \mathrm{s}), 7.19-7.26(2 \mathrm{H}, \mathrm{m}), 7.50-7.56(2 \mathrm{H}, \mathrm{m}), 9.77(1 \mathrm{H}, \mathrm{s}) . \mathrm{IR}(\mathrm{KBr})$ $\mathrm{cm}^{-1}: 1761,1732,1495,1208,1148,1019$. Anal. Calcd for $\mathrm{C}_{16} \mathrm{H}_{17^{-}}$ $\mathrm{ClFNO}_{4} \mathrm{~S}$ : C, 47.35; H, 4.22; N, 3.45. Found: C, 47.56; H, 4.16; N, 3.39.

[(2,2-Dimethylpropanoyl)oxy]methyl (6RS)-6-[ $N$-(2-Chloro-4-fluorophenyl)sulfamoyl|cyclohex-1-ene-1-carboxylate (9b) Iodomethyl pivalate $(0.29 \mathrm{~g})$ was added to a solution of $8(0.36 \mathrm{~g})$ in DMF $(3 \mathrm{ml})$ and the mixture was stirred for $8 \mathrm{~h}$, then worked up (EtOAc; water, brine). The residue was purified by silica gel column chromatography (EtOAc-hexane, $1: 3$, $\mathrm{v} / \mathrm{v})$ to give $9 \mathrm{~b}(0.28 \mathrm{~g}, 62 \%)$ as a colorless oil: ${ }^{1} \mathrm{H}-\mathrm{NMR}$ (DMSO- $\left.d_{6}\right) \delta: 1.11$ $(9 \mathrm{H}, \mathrm{s}), 1.6-2.4(6 \mathrm{H}, \mathrm{m}), 4.30(1 \mathrm{H}, \mathrm{br}), 5.68(2 \mathrm{H}, \mathrm{s}), 7.18-7.78(4 \mathrm{H}, \mathrm{m})$, $9.74(1 \mathrm{H}, \mathrm{s})$. FAB-MS $m / z: 447\left(\mathrm{M}^{+}\right)$.

2-Amino-2-oxoethyl (6RS)-6-[ $N$-(2-Chloro-4-fluorophenyl)sulfamoyl]cyclohex-1-ene-1-carboxylate (9c) Compound 9c was prepared in $42 \%$ yield by the reaction of $\mathbf{8}$ with bromoacetamide, as white powdery crystals, mp $146-148^{\circ} \mathrm{C} .{ }^{1} \mathrm{H}-\mathrm{NMR}$ (DMSO- $\left.d_{6}\right) \delta: 1.60-1.85(2 \mathrm{H}, \mathrm{m}), 2.00-2.42$ $(4 \mathrm{H}, \mathrm{m}), 4.38(2 \mathrm{H}, \mathrm{s}), 4.41(1 \mathrm{H}, \mathrm{d}, J=5.2 \mathrm{~Hz}), 7.19-7.29(4 \mathrm{H}, \mathrm{m}), 7.49-$ $7.57(2 \mathrm{H}, \mathrm{m}), 9.75(1 \mathrm{H}, \mathrm{s})$. Anal. Calcd for $\mathrm{C}_{15} \mathrm{H}_{16} \mathrm{ClFN}_{2} \mathrm{O}_{5} \mathrm{~S}: \mathrm{C}, 46.10 ; \mathrm{H}$, 4.13 ; N, 7.17. Found: C, 46.33; H, 4.24; N, 7.10.

Acetoxymethyl (6R)-6-[ $N$-(2-Chloro-4-fluorophenyl)sulfamoyl]cyclohex-1-ene-1-carboxylate $[(\boldsymbol{R})-9 \mathrm{a}]$ A mixture of 9a (10 g), Lipase PS-D $(6.0 \mathrm{~g})$, water $(20 \mathrm{ml})$ and acetone $(200 \mathrm{ml})$ was stirred for $17.5 \mathrm{~h}$ at $28^{\circ} \mathrm{C}$. The catalyst was removed by filtration. The filtrate was worked up $\left(\right.$ iso- $\operatorname{Pr}_{2} \mathrm{O}$, EtOAc; saturated aqueous $\mathrm{NaHCO}_{3}$, water, brine) to give $(R)-9 \mathrm{a}(4.82 \mathrm{~g}$, $48 \%$ ) as a colorless oil. The ee of $(R)-9$ a obtained was determined to be $>99 \%$ ee [column, CHIRALCEL OC; mobile phase, hexane-EtOH-TFA, 
$8: 2: 0.01$; flow rate, $1.1 \mathrm{ml} / \mathrm{min}$; detection, $\mathrm{UV}$ at $225 \mathrm{~nm}$; retention time, $(R)-9 \mathrm{a}: 16.3 \mathrm{~min},(S)-3: 9.97 \mathrm{~min}] .{ }^{1} \mathrm{H}-\mathrm{NMR}\left(\mathrm{DMSO}-d_{6}\right) \delta: 1.53-1.89(2 \mathrm{H}$, m), $2.02(3 \mathrm{H}, \mathrm{s}), 2.02-2.43(4 \mathrm{H}, \mathrm{m}), 4.29(1 \mathrm{H}, \mathrm{d}, J=5.2 \mathrm{~Hz}), 5.64(2 \mathrm{H}, \mathrm{s})$, $7.19-7.23(2 \mathrm{H}, \mathrm{m}), 7.49-7.57(2 \mathrm{H}, \mathrm{m}), 9.76(1 \mathrm{H}, \mathrm{s}) . \mathrm{IR}(\mathrm{KBr}) \mathrm{cm}^{-1}$ : $1761,1732,1495,1208,1148,1019 .[\alpha]_{\mathrm{D}}^{20}+84.0^{\circ}(c=0.205, \mathrm{MeOH})$.

Ethyl (6R)-6-[ $\boldsymbol{N}$-(2-Chloro-4-fluorophenyl)sulfamoyl]cyclohex-1-ene-1carboxylate $[(\boldsymbol{R})-1]$ [Method a]: A mixture of $\left(6 R, 1^{\prime} S\right)-6(10.5 \mathrm{~g}, 58.8 \%$ de), conc. $\mathrm{H}_{2} \mathrm{SO}_{4}(5.0 \mathrm{ml})$ and $\mathrm{EtOH}(200 \mathrm{ml})$ was heated under reflux for $15 \mathrm{~h}$. After the addition of conc. $\mathrm{H}_{2} \mathrm{SO}_{4}(2.0 \mathrm{ml})$, the whole was refluxed further $11 \mathrm{~h}$ and cooled. The mixture was concentrated under reduced pressure, then worked up (EtOAc; ice-water, aqueous $\mathrm{NaHCO}_{3}$, brine). The residue was purified by silica gel column chromatography (EtOAc-hexane, 1:5 $\rightarrow$ $1: 4, \mathrm{v} / \mathrm{v})$ followed by recrystallization from EtOH to give $(R)-1(2.55 \mathrm{~g}$, $37 \%$ ) as colorless powdery crystals with $>99 \%$ ee [column, CHIRALPAK $\mathrm{AD}$; mobile phase, EtOH-hexane, $9: 1$; flow rate, $0.6 \mathrm{ml} / \mathrm{min}$; detection, UV at $254 \mathrm{~nm}$; retention time, $(R)-\mathbf{1}: 20.0 \mathrm{~min},(S)-\mathbf{1}: 16.7 \mathrm{~min}]$.

[Method b]: A mixture of $(R)-3(2.5 \mathrm{~g},>99 \%$ ee $)$, conc. $\mathrm{H}_{2} \mathrm{SO}_{4}(2.5 \mathrm{ml})$ and $\mathrm{EtOH}(50 \mathrm{ml})$ was heated under reflux for $19 \mathrm{~h}$. The reaction mixture was cooled and worked up (EtOAc; water, $0.5 \mathrm{~N} \mathrm{NaOH}, 0.5 \mathrm{~N} \mathrm{HCl}$, brine). The residue was purified by flash silica gel column chromatography (EtOAchexane, $1: 10 \rightarrow 1: 3, \mathrm{v} / \mathrm{v})$ and crystallized from EtOH-hexane to give $(R)-1$ $(1.94 \mathrm{~g}, 72 \%)$ as colorless prisms with $>99 \%$ ee.

[Method c]: A mixture of $(R)-9 a(4.8 \mathrm{~g},>99 \%$ ee $)$, conc. $\mathrm{H}_{2} \mathrm{SO}_{4}(4.8 \mathrm{ml})$ and $\mathrm{EtOH}(96 \mathrm{ml})$ was heated under reflux for $25 \mathrm{~h}$ and cooled. The reaction mixture was concentrated under reduced pressure, then worked up (EtOAc; ice-water, saturated aqueous $\mathrm{NaHCO}_{3}$, brine). The residue was purified by silica gel column chromatography (EtOAc-hexane, 1:3, v/v) and crystallized from EtOH-hexane to give $(R)-1(2.76 \mathrm{~g}, 65 \%)$ as colorless prisms with $>99 \%$ ee. mp $68-69^{\circ} \mathrm{C} .{ }^{31)}{ }^{1} \mathrm{H}-\mathrm{NMR}$ (DMSO- $\left.d_{6}\right) \delta: 1.05(3 \mathrm{H}, \mathrm{t}, J=$ $7.0 \mathrm{~Hz}), 1.56-1.83(2 \mathrm{H}, \mathrm{m}), 2.01-2.43(4 \mathrm{H}, \mathrm{m}), 4.00(2 \mathrm{H}, \mathrm{q}, J=7.0 \mathrm{~Hz})$, $4.30(1 \mathrm{H}, \mathrm{d}, J=5.0 \mathrm{~Hz}), 7.10(1 \mathrm{H}, \mathrm{br}), 7.20-7.30(1 \mathrm{H}, \mathrm{m}), 7.50-7.58(2 \mathrm{H}$, $\mathrm{m}), 9.74(1 \mathrm{H}, \mathrm{s}) . \mathrm{IR}(\mathrm{KBr}) \mathrm{cm}^{-1}: 1711,1649,1493,1333,1150 .[\alpha]_{\mathrm{D}}^{20}$ $+111.0^{\circ}(c=1.0, \mathrm{MeOH})$. Anal. Calcd for $\mathrm{C}_{15} \mathrm{H}_{17} \mathrm{ClFNO}_{4} \mathrm{~S}: \mathrm{C}, 49.79 ; \mathrm{H}$, 4.74; N, 3.87. Found: C, 49.73; H, 4.69; N, 3.81.

These products $(R)-\mathbf{1}$ obtained by the three methods described above, respectively, were identical to TAK-242 prepared by optical resolution by preparative HPLC ${ }^{5)}$ upon direct comparison with the authentic sample.

Acknowledgements We thank Drs. A. Miyake, K. Itoh and S. Hashiguchi for helpful discussions throughout this work; Drs. D. Cork and A. Hasuoka for development of the synthesis of key intermediate 3 .

\section{References and Notes}

1) Rangel-Frausto M. S., Pittet D., Costigan M., Hwang T., Davis C. S., Wenzel R. P., JAMA, 273, 117-123 (1995).

2) Hotchkiss R. S., Karl I. E., N. Engl. J. Med., 348, 138-150 (2003).

3) Martin G. S., Mannino D. M., Eaton S., Moss M., N. Engl. J. Med., 348, 1546-1555 (2003).

4) Bernard G. R., Vincent J. L., Laterre P. F., LaRosa S. P., Dhainaut J. F., Lopez-Rodriguez A., Steingrub J. S., Garber G. E., Helterbrand J. D., Ely E. W., Fisher C. J., N. Engl. J. Med., 344, 699-709 (2001).

5) Yamada M., Ichikawa T., Ii M., Sunamoto M., Ito K., Tamura N., Kitazaki T., J. Med. Chem., 48, 7457-7467 (2005).

6) Fujii A., Hashiguchi S., Uematsu N., Ikariya T., Noyori R., J. Am. Chem. Soc., 118, 2521-2522 (1996).
7) The stereochemistry of the major isomer was confirmed to be $\left(6 R, 1^{\prime} S\right)$ after converting to compound $\mathbf{1}$.

8) Diastereomeric excesses (de's) were determined by the HPLC on an ODS column.

9) The stereochemistry of the major diastereomeric ester was confirmed to be $\left(6 R, 1^{\prime} R\right)$ by the same method described in ref. 7 .

10) Diastereomeric excesses (de's) were determined by the HPLC on a silica gel column.

11) Enantiomeric excesses (ee's) were determined by the HPLC on a chiral column (Daicel, CHIRALPAK AD).

12) When direct transesterification of $\left(6 R, 1^{\prime} R\right)-7$ to $(R)-1$ was attempted using the same method used for $\left(6 R, 1^{\prime} S\right)-6$, only decomposition products were obtained.

13) For review see: Santaniello E., Ferraboschi P., Grisenti P., Manzocchi A., Chem. Rev., 92, 1071-1140 (1992).

14) For review see: Mori K., Synlett, 1995, 1097-1109 (1995).

15) For review see: Robert S. M., J. Chem. Soc., Perkin Trans. 1, 1998, 157-169 (1998).

16) For review see: Robert S. M., J. Chem. Soc., Perkin Trans. 1, 1999, $1-12$ (1999).

17) For review see: Whitesides G. M., Wong C. H., Angew. Chem., Int. Ed. Engl., 24, 617-718 (1985).

18) For review see: Boland W., Frößl C., Lorenz M., Synthesis, 1991, 1049-1072 (1991).

19) Sakamoto K., Tsuzaki K., Shima M., JP 09308497 (1997) [Chem. Abstr., 128, 74400 (1997)].

20) Yanase H., Arishima T., Kita K., Nagai J., Mizuno S., Takuma Y., Endo K., Kato N., Biosci. Biotech. Biochem., 57, 1334-1337 (1993).

21) Brieva R., Crich J. Z., Sih C. J., J. Org. Chem., 58, 1068-1075 (1993).

22) Ebiike H., Terao Y., Achiwa K., Tetrahedron Lett., 32, 5805-5808 (1991).

23) Ebiike H., Matsuyama K., Achiwa K., Chem. Pharm. Bull., 40, 1083-1085 (1992).

24) The stereochemistry of (R)-9a was confirmed after converting to compound 1. Enantiomeric excesses (ee's) were determined by the HPLC on a chiral column (Daicel, CHIRALCEL OC).

25) Although dicyclohexylamine, sodium carbonate, lithium carbonate and $\mathrm{K}_{2} \mathrm{CO}_{3}$ were used as another base, the yields of $9 \mathbf{a}$ were not superior to that of $\mathrm{Cs}_{2} \mathrm{CO}_{3}$.

26) Lipase AK-20 from Pseudomonas fluorescens, Lipase PS from Pseudomonas cepacia, Lipase F from Pseudomonas fluorescens and Lipase QLG from Alcaligenes sp.

27) Chen C.-S., Fujimoto Y., Girdaukas G., Sih C. J., J. Am. Chem. Soc., 104, 7294-7299 (1982).

28) The enantiomeric ratio ( $E$ value) was calculated from $E=$ $\ln \left[(1-c)\left(1-e_{s}\right)\right] / \ln \left[(1-c)\left(1+e_{s}\right)\right]$, where $c=e_{s} /\left(e_{s}+e e_{p}\right)$.

29) Lipase PS-D is a trade name for Pseudomonas cepacia lipase immobilized on diatomaceous earth.

30) Adlercreutz P., "Enzymatic Reactions in Organic Media," ed. by Koskinen A. M. P., Klibanov A. M., Wiley-VCH, Weinheim, 1996, p. 9.

31) The melting point of compound $(R)-\mathbf{1}$ obtained above was different from that of $(R)-1$ in ref. 5; the crystal form of each compound was different due to different solvents used for recrystallization. 